2. Пилипчук I.C., Пилипчук C.I. Патологія пуповини: сучасні погляди на проблему: колект. монографія. Люблін: Люблінський медичний університет, 2021. $436 \mathrm{c.}$

3. Чагаев Ч.Г. Патология пуповины / под ред. В.Е. Радзинского. Москва, 2011.95 с.

4. Экстраэмбриональные и околоплодные структуры при нормальной и осложненной беременности / за ред. В.Е. Радзинского, А.П. Милованова. Москва, 2004. 393 с.

5. Collins J.H., Collins C.L., Collins C.C. Umbilical cord accidents, 2004. $72 \mathrm{p}$.

6. Machin G.A. Abnormal umbilical cord coiling is associated with adverse perinatal outcomes. Pediatr. Dev Pathol. 2000; №3 (5). P. 462-471.

DOI https://doi.org/10.30525/978-9934-26-075-9-22

\title{
MORPHOLOGICAL CHANGES OF RATS LEFT VENTRICLE MYOCARDIUM UNDER THE INFLUENCE OF INFUSION SOLUTIONS
}

\author{
Radoha R. V. \\ Candidate of Medical Sciences, \\ Associate Professor at the Department of Human Anatomy \\ National Pirogov Memorial Medical University \\ Fomina L. V. \\ $M D$, Doctor of Medical Sciences, \\ Professor at the Department of Human Anatomy \\ National Pirogov Memorial Medical University \\ Guminskiy Yu. I. \\ $M D$, Doctor of Medical Sciences, \\ Professor at the Department of Human Anatomy \\ National Pirogov Memorial Medical University \\ Vinnytsya, Ukraine
}

Topicality: Burns are thermal injuries that affect humanity since antient times. Scientists all over the world are searching for an appropriate and effective methods of treatment [1, p. 328]. Data from hospitalized burn patients worldwide reveal from $3 \%$ to $10 \%$. The average proportion of the 
body surface area burned is approximately $20 \%$. [2, p. 630]. The survival rate for admitted burn patients has improved recently [3, p. 215] and is currently a favorable $97 \%$ for patients admitted to burn centers [4, p. 2]. To our minds, this sed statistics motivate investigations in this area.

Objective: To detect morphological changes in the myocardium of healthy rats under the action of infusion solutions used in the treatment of burn injuries.

Materials and methods: This work is a fragment of the scientific study "Experimental justification of the effectiveness of complex infusion drugs in the model of burn disease in animals", № state. registration 0110U002590. All manipulations and keeping of animals were carried out in accordance with the "General Ethical Principles of Animal Experiments" adopted by the First National Congress on Bioethics (Kyiv, 2001), and were guided by the recommendations of the European Convention on Vertebrate Animals for Experimental and Other Scientific Purposes. goals» (Strasbourg, 1985) and the provisions of the «Rules of preclinical safety assessment of pharmacological agents (GLP)», fully complied with the rules of humane treatment of experimental animals, approved by the Committee on Bioethics of National Pirogov Memorial Medical University, Vinnytsya (protocol № 1 of 14.01.2010). To objectively evaluate the comparison of the results of myocardium morphological examination under the burn injury and treatment, to avoid the influence of errors associated with the action of solutions administered as therapeutic measures, 3 groups of comparison rats were administered, which were injected with saline, lactoprotein and sorbitol and the drug HAES-LX-5\% without causing burn injury [5, p. 69].

The studies were performed on the first, third and seventh days. Rats of all three groups were in vivarium on a standard diet for rats, drinking was not restricted. Saline, lactoprotein with sorbitol and HAES-LX-5\% were administered. The microscopic method of research was applied.

Results: The group, which was injected with saline, included 26 experimental animals. On microscopic examination, the myocardium had a typical histological structure. Functional elements were represented by integral cardiomyocytes. The mathematical expectation of the diameter of cardiomyocytes was: on the first day of the experiment $(14.1 \pm 0.4) \mu \mathrm{m}$, on the third $-(11.9 \pm 0.5) \mu \mathrm{m}$, on the seventh $-(15.3 \pm 0.7) \mu \mathrm{m}$, the area their cross section is $(161.5 \pm 8.1) \mu^{2},(113.3 \pm 5.2) \mu \mathrm{m}^{2}$ and $(174.2 \pm 8.3) \mu \mathrm{m}^{2}$, respectively. One (sometimes two) round-oval nucleus with evenly distributed heterochromatin was located in the central departments of cardiomyocytes. The cross-sectional area of the nuclei, on average, was equal to: $(29.8 \pm 1.01)$ $\mu \mathrm{m}^{2}$ on the first day, $(27.7 \pm 1.27) \mu \mathrm{m}^{2}$ on the third and $(28.7 \pm 1.1) \mu \mathrm{m}^{2}$ on the 
seventh day experiment. The width of the perimysium zone: on the first day of the experiment $(29.5 \pm 1.2) \mu \mathrm{m}$, on the third $-(33.8 \pm 1.5) \mu \mathrm{m}$, on the seventh $-(25.3 \pm 1.0) \mu \mathrm{m}$, endomysium $-(4.9 \pm 0.2) \mu \mathrm{m},(5.1 \pm 0.2) \mu \mathrm{m}$ and $(4.6 \pm 0.2) \mu \mathrm{m}$, respectively. Cellular elements of inflammation in the stroma were absent, there was a relatively uniform blood supply to the intramyocardial vessels of the hemomicrocirculatory tract. The endothelium and the structure of the vascular wall of the hemomicrocirculatory tract had a normal appearance.

Thus, the infusion of saline to experimental animals without burn injury did not lead to any pathological changes.

In the group of rats injected with a solution of lactoprotein with sorbitol at the histological level, we did not notice structural changes. The thickness of cardiomyocyte fibers, on average, was: on the first day of the experiment $(12.5 \pm 0.5) \mu \mathrm{m}$, on the third - (14.2 \pm 0.7$) \mu \mathrm{m}$, on the seventh $-(11.8 \pm 0.5))$ $\mu \mathrm{m}$, their cross-sectional area is $(118.3 \pm 5.9) \mu \mathrm{m} 2,(154.0 \pm 6.6) \mu \mathrm{m}^{2}$ and $(110.5 \pm 5.5) \mu \mathrm{m}^{2}$, respectively. The nuclei were rounded. Chromatin in the nuclei was evenly distributed. The cross-sectional area of the nuclei, on average, was equal to: $(27.5 \pm 1.4) \mu \mathrm{m}^{2}$ on the first day, $(28.2 \pm 1.4) \mu \mathrm{m}^{2}$ on the third and $(33.3 \pm 1.7) \mu \mathrm{m}^{2}$ on the seventh day experiment. The stroma was without signs of edema, free from cellular elements of inflammation. The width of the perimysium zone was, on average: on the first day - (32.0 \pm 1.9$)$ microns, on the third $-(31.2 \pm 1.6)$ microns, on the seventh $-(33.6 \pm 1.6)$ microns, endomysium $-(5.3 \pm 0.2) \mu \mathrm{m},(5.6 \pm 0.2) \mu \mathrm{m}$ and $(4.7 \pm 0.2) \mu \mathrm{m}$, respectively. The blood supply to the intramyocardial vessels of the hemomicrocirculatory tract was uniform.

Thus, in the myocardium of experimental animals without burn injury, after the introduction of lactoprotein with sorbitol, at the histological level, we found no structural disorders.

Microscopic examination of the myocardium in rats without thermal damage, after administration of the drug HAES-LX-5\%, we observed its normal histological structure.

The thickness of cardiomyocytes, on average, was: on the first day of the experiment $(13.1 \pm 0.7) \mu \mathrm{m}$, on the third $-(14.4 \pm 0.7) \mu \mathrm{m}$, on the seventh $(12.6 \pm 0.6)) \mu \mathrm{m}$, their cross-sectional area is $(134.2 \pm 6.7) \mu \mathrm{m}^{2},(163.8 \pm 8.7)$ $\mu \mathrm{m}^{2}$ and $(127.3 \pm 6.1) \mu \mathrm{m}^{2}$, respectively. The cross-sectional area of the nuclei, on average, was: on the first day $(32.9 \pm 1.6) \mu \mathrm{m} 2,(31.8 \pm 1.7) \mu \mathrm{m}^{2}$ on the third and $(29.6 \pm 1.6) \mu \mathrm{m}^{2}$ on the seventh day experiment. We also did not notice signs of inflammation, edema of the stroma. The width of the perimysium zone was, on average: on the first day of the experiment (31.5 \pm 1.5) $\mu \mathrm{m}$, on the third $-(37.4 \pm 1.9) \mu \mathrm{m}$, on the seventh $-(33.9 \pm 1.6) \mu \mathrm{m}$, 
endomysium $-(4.7 \pm 0.2) \mu \mathrm{m},(5.2 \pm 0.3) \mu \mathrm{m}$ and $(5.0 \pm 0.3) \mu \mathrm{m}$, respectively. The blood supply to the vessels of the hemomicrocirculatory tract over the entire area of the sections was moderate, uniform.

Thus, within seven days after administration of HAES-LX-5\% to animals without burn injury, histological examination of their myocardium, we did not notice any pathological changes.

Conclusion: In general, it can be stated that the introduction of intact animals' saline, lactoprotein solution with sorbitol and HAES-LX-5\% did not adversely affect the left ventricular myocardium, and did not lead, in due time, to its morphological changes in tissue levels. Histological structure of the left ventricular myocardium, morphometric parameters in these groups of animals did not differ significantly.

\section{References:}

1. Hettiaratchy S, Dziewulski P. ABC of burns: pathophysiology and types of burns. BMJ. 2004 Jun 12;328(7453):1427-9. doi: 10.1136/bmj.328. 7453.1427. Erratum in: BMJ. 2004 Jul 17;329(7458):148. PMID: 15191982; PMCID: PMC421790.

2. Peck MD. Epidemiology of burns throughout the World. Part II: intentional burns in adults. Burns. 2012 Aug;38(5):630-7. doi: 10.1016/j.burns.2011.12.028. Epub 2012 Feb 9. PMID: 22325849.

3. Mann R, Heimbach D. Prognosis and treatment of burns. West J Med. 1996;165:215-20.

4. American Burn Association. Burn incidence and treatment in the United States: 2013 fact sheet. 2013. http://www.ameriburn.org/resources_ factsheet.php. Accessed 12 May 2015

5. Морфологічні зміни у міокарді щурів в умовах інфузійної корекції експериментальної опікової хвороби / Л. В. Фоміна, Р. В. Радьога // Український журнал медицини, біології та спорту. 2017. - № 5 (7). - С. 69-73. 